\title{
Penerapan MOORA pada Evaluasi Kinerja dalam Mengefektifkan Biaya Operasional
}

\author{
Arridha Zikra Syah ${ }^{1 *}$, Yessica Siagian ${ }^{2}$ \\ Program Studi Sistem Informasi, STMIK Royal Kisaran, Kisaran, Indonesia \\ Email: 1,*azsyra@gmail.com, ${ }^{2}$ yessica.cyg123@gmail.com \\ Email Penulis Korespondensi: azsyra@gmail.com
}

\begin{abstract}
Abstrak-Evaluasi Kinerja sales merupakaan tahapan dalam melakukan pemerikasaan dan penilaian terhadap pencarian informasi Kinerja atau hasil kerja karyawan/pekerja dalam bidang sales pada sebuah perusahaan, hal tersebut dilakukan dalam upaya mengefektifkan biaya operasional perusahaan dikarenakan seorang sales merupakan puncak dalam pencapaian dan perputaran biaya operasional sebuah perusahaan, dilakukan oleh seorang sales dimana seorang sales tentunya melakukan penjualan produk yang diproduksi perusahaan atau oranisasi dengan tingkat penjualan yang sudah ditentukan, sehingga perlu dilakukan penilaian atau evaluasi Kinerja sales dalam rangka menunjuk dan mengetahui tingkat kualitas Kinerja sales, memberikan reward kepada Kinerja sales yang baik akan meningkatkan motivasi dan semangat pencapaian kerja sales sehingga mampu mengefektidkan biaya operasional, dilakukan sebuah pemilihan secara tersistem menggunakan metode MOORA (Multi- Objective Optimization On The Basis Of Ratio Analysis) dalam pengukuran evaluasi Kinerja sales agar dalam proses pelaksanaan lebih terstruktur serta berjalan dengan jujur dan adil. Hasil yang didapatkan dalam penelitian bahwa alternatif A1 merupakan sales yang memiliki kinerja terbaik dengan nilai 0,546616.
\end{abstract}

Kata Kunci: Evaluasi Kinerja Sales; SPK; Metode MOORA

Abstract-Sales performance evaluation is a stage in conducting an examination and assessment of information seeking performance or work results of employees / workers in the sales field of a company, this is done in an effort to streamline the company's operational costs because a salesperson is the peak in the achievement and turnover of an operational cost. company, carried out by a salesperson where a salesperson certainly sells products produced by the company or organization with a predetermined sales level, so it is necessary to conduct an assessment or evaluation of sales performance in order to appoint and find out the quality level of sales performance, to reward good sales performance will increase motivation and enthusiasm for sales work achievement so as to be able to streamline operational costs, a systemized selection is made using the MOORA (Multi-Objective Optimization On The Basis Of Ratio Analysis) method. in measuring sales performance evaluation so that the implementation process is more structured and runs honestly and fairly. The results obtained in the study that alternative A1 is a sales that has the best performance with a value of 0.546616 .

Keywords: Sales Performance Evaluation; DSS; MOORA Method

\section{PENDAHULUAN}

Pertumbuhan ekonomi Indonesia yang terus memulai untuk maju dan berkembang dikarenakan terus berdiri perusahaan-perusahaan hebat dalam bidangnya sehingga meningkatkan terbukanya lapangan kerja perusahaan yang membantu pemerintah Indonesia dalam membuka lapangan kerja di Indonesia. Tumbuh kembangnya sebuah perusahaan tidak lepas dari perjuangan dari Sales yang melakukan pemasaran terhadap produk yang diproduksi oleh sebuah perusahaan.

sales itu sendiri adalah seseorang memastikan mengenalkan produk dengan baik dan mencari tahu apa yang dibutuhkan oleh calon pembeli dan memberikan keyakinan terhadap calon pembeli untuk membeli produk yang ditawarkannya sehingga seorang sales dapat dikatakan sebagai penggerak utama dan penghasil biaya dan meningkatkan biaya operasional sebuah perusahaan, semakin tinggi kualitas dan kinerja yang diberikan oleh sales kepada perusahaan maka semakin baik tumbuh kembang perusahaan tersebut[1].

Pekerjaan sales sering sekali merupakan pekerjaan yang cukup menakutkan bagi masyarakat luas dikarenakan harus memiliki tekat dan target dalam memenuhi penjualan produk dari perusahaan, hal tersebut dilakukan untuk meningkatkan pencapaian terhadap tujuan perusahaan seperti memperoleh laba berupa keuangan, produk semakin terkenal di kalangan masyarakat luas, hal tersebut berpengaruh besar kepada perusahaan sehinngga laju operasional semakin berjalan yang berarti sales berpengaruh dalam mengefektifkan biaya operasional sebuah perusahaan[2].

Salah satu masalah yang dihadapi oleh sebuah perusahaan terhadap sales adalah kecenderungan memilih berhenti bekerja, tidak mencapai target dan tidak semangat dalam bekerja yang mengakibatkan perusahaan mengalami penurunan terhadap keuntungan yang diperoleh perusahaan dan tentunya berdampak kepada menurunya biasa operasional perusahaan. Biaya operasional itu sendiri merupakan keseluruhan biaya operasional yang memuat aspek kegiatan yang dilakukan sebuah bisnis dalam menjalankan dan mengahasilkan suatu produk, biaya ini menyangkut dengan biaya belanja modal, biaya penyediaan komponen, biaya pengembangan, biaya sumber daya, pemeliharaan dan lain-lain.

Untuk tetap mempertahankan tingkat efektifiktas biaya operasional salah satu hal yang dapat dilakukan adalah memberikan motivasi kepada sales berupa reward dengan cara melakukan evaluasi kinerja sales, salah satu evaluasi kinerja sales dapat dilakukan dengan melihat nilai terhadap kegiatan dan aktivitas yang berhubungan dengan kinerja kerja sales, sehingga hal tersebut dapat menjadi cara kontrol perusahaan terhadap 
menjaga stabilitas dan semangat kinerja sales. Kerap sekali dalam melakukan evaluasi kinerja sales terjadi kesalahan dalam melakukan input nilai, keterlambatan dalam menemukan hasil hingga kesulitan dalam melihat tingkat akurasi atau persentase dalam menentukan nilai terhadap evaluasi kinerja sales dikarenakan terdapat banyak data yang akan diproses sehingga diperlukan sebuah sistem pengambilan keputusan dalam mempermudah menyelesaikan permasalahan evaluasi kinerja sales dalam mengefektifkan biaya operasional[3]. Sistem Pendukung Keputusan (SPK) merupakan suatu sistem yang mampu memberikan dukungan terhadap keputusan yang dihasilkan pimpinan/manajemen berbasis komputer[4], [5]. Dalam SPK terdapat beberapa metode yang biasa di gunakan, diantaranya metode SAW, WP, TOPSIS, ELECTRE, MOORA dan lainnya[6].

Penggunaan metode MOORA (Multi-Objective Optimization on The Basis of Ratio Analysis) banyak digunakan oleh peneliti sebelumnya seperti penelitian untuk menentukan kualifikasi terhadap penerima bantuan beasiswa atau bantuan siswa miskin, pada penelitian ini dilakukan tahapan penerapan metode metode MOORA (Multi- Objective Optimization On The Basis Of Ratio Analysis) untuk menghitung setiap kriteria yang dimiliki oleh kandidat penerima bantuan berdasarkan spesifikasi yang diharapkan oleh pengelola pemberi bantuan [7].

Penelitian lainnya metode MOORA (Multi-Objective Optimization on The Basis of Ratio Analysis) digunakan untuk menentukan kualitas terhadap buah mangga dengan melihat unsur yang mempengaruhi buah mangga yang baik kualitasnya sehingga penerapan metode MOORA (Multi- Objective Optimization On The Basis Of Ratio Analysis) membantu dalam melengkapi proses dan tahapan perhitungan untuk mendapatkan kualitas mangga terbaik dan hasilnya menunjukan jenis mangga yang memiliki kualitas terbaik dengan menghasilkan informasi terhadap krtiteria apa saja yang menyatakan kualitas mangga akan dikategorikan sebagai mangga berkualitas dan menghasilkan informasi tingkat 1 sampai tinggat $\mathrm{n}$ [8].

Penelitian terdahulu lainnya metode MOORA (Multi-Objective Optimization on The Basis of Ratio Analysis) membantu dalam menentukan guru dan pegawai terbaik dimana dalam tahapan penelitian menggunakan metode ini bertujuan untuk memberikan penilaian terhadap guru maupun pegawai dengan tujuan mengetahui pegawai dan guru terbaik sehingga dengan melakukan hal tersebut diketahui kualitas masing-masing pegawai maupun guru yang bertujuan untuk meningkatkan kinerja dan memberikan motivasi dalam menyajikan yang terbaik dalam hal pekerjaan yang guru maupun pegawai tekunin [9].

Pada penelitian ini penyelesaian masalah menggunakan pendekatan menggunakan metode MOORA (Multi-Objective Optimization on The Basis of Ratio Analysis) dimana metode ini merupakan metode yang paling sederhana dan memiliki tingkat akurasi dalam membantu penyelesaian masalah dalam hal penilaian dan pengambilan keputusan sehingga hasil akan lebih efektif dan akurat. Pada penelitian dilakukan penilaian terhadap evaluasi kinerja sales terhadap sales achievement (pencapaian penjualan), sales call effectivity (efektivitas kunjungan penjualan), sales promotion program, market condition (kondisi pasar) hal tersebut dilakukan untuk memberikan informasi kepada salesman terhadap kinerja sales yang harus dipenuhi dengan menggunakan penilaian yang dirangkum dengan menerapkan metode MOORA (Multi-Objective Optimization on The Basis of Ratio Analysis) berdasarkan penelitian terdahulu metode ini membantu banyak kasus dalam pengambilan keputusan dengan akurasi yang tinggi.

\section{METODOLOGI PENELITIAN}

Metodologi penelitian sangat penting dilakukan untuk membantu segala kegiatan penelitian dalam memperlihatkan langkah-langkah hingga penyelesaian masalah yang terdapat dalam sebuah penelitian, dalam sebuah metodologi penelitian terdapat dua jenis seperti metodologi penelitian kuantitatif dan metodologi penelitian kualitatif. Pada metodologi penelitian ini menerapkan penelitian kuantitatif yaitu pada penelitian ini menyajikan secara kuantitatif yang berhubungan dengan sistem dan hasil nilai (matematika), dalam sebuah penelitian tentunya harus diketahui terhadap cara pengumpulan data dan penelitian secara teoristis[10].

\subsection{Pengumpulan data}

Pengumpulan data dilakukan teknik analisa terkait kendala perusahaan dan fenomena dari dokumentasi kinerja sales dan pendapatan sales yang selanjutnya dilakukan teknik studi pustaka untuk mengetahui kiat dan hal apa saja yang harus dipersiapkan dan diketahui untuk menunjang efektif biaya operasional sebuah perusahaan dan mengetahui tahapan yang dilakukan dalam pengumpulan data untuk membantu penyelesaian permasalahan dalam sebuah penelitian baik berupa data, penggunaan metode hingga keseluruhan teoristis dan pengujian yang dilakukan sehingga mempermudah peneliti dalam memahami alur pada setiap kegiatan penelitian[11].

\subsection{Sales}

Sales merupakan anggota penting sebuah perusahaan dan merupakan anggota yang memiliki tugas inti dari adanya sebuah perusahaan dan sales merupakan motor penggerak laju kembang perusahaan yang bertujuan memperkenalkan, memberikan layanan dan penyajian informasi yang tepat terhadap produk maupun layanan jasa yang disediakan oleh perusahaan. Cara sales berkerja dengan mendatangi langsung target atau konsumen pasar dan meyakinkan pembeli atau konsumen untuk membeli produk maupun jasa yang tawarkan oleh sales 
tersebut dan terjadilah proses transaksi antara pembeli sales langsung dilakukan pada waktu yang bersamaan[12].

\subsection{Evaluasi Kinerja Sales}

Evaluasi kinerja berasal dari dua kata yaitu evaluasi yang berarti penaksiran atau sebuah acuan terhadap anjuran penilaian terhadap suatu hal yang ingin dilakukan, dapat dilakukan evaluasi dikarenakan sudah dilakukan penilaian terdahulu sementara kinerja merupakan sebuah gambaran terhadap prestasi kerja sehingga dapat dikatakan evaluasi kinerja sales merupakan gambaran terhadap penilaian kinerja maupun pencapaian kinerja kerja sales.

\subsection{Metode Multi-Objective Optimization on The Basis of Ratio Analysis (MOORA)}

MOORA (Multi- Objective Optimization on The Basis of Ratio Analysis) merupakan salah satu metode dalam menentukan keputusan yang diperkenalkan oleh Brauers dan Zavadskas pada tahun 2006, metode ini memiliki tahapan penyelesaian permasalahan sangan mudah untuk dipahami dan diimplementasikan dalam sebuah penelitian, metode ini dapat digunakan untuk mengerjakan beberapa penyelesaian permasalahan sepeti dalam bidang ekonomi, managerial, pengambilan keputusan dalam lingkungan perusahaan dan lain-lain[13]-[15]. Berikut ini merupakan tahapan dalam penyelesaian masalah menggunakan metode MOORA [16]-[20], adalah:

1. Pembentukan Matriks

Pada tahapan ini nilai kriteria dari masing-masing alternatif yang sudah berbentuk nominal angka diterapkan dalam bentuk matriks untuk mempermudah proses perhitungan selanjutnya, tampilan matriks pada implementasi metode Moora ini sebagai berikut:

$x_{i j}=\left|\begin{array}{cccc}x_{11} & x_{12} & x_{13} & x_{1 n} \\ x_{21} & x_{22} & x_{23} & x_{2 n} \\ \cdot & \cdot & \cdot & \cdot \\ x_{m 1} & x_{m 2} & x_{m 3} & x_{m n}\end{array}\right|$

$\mathrm{X}$ dinyatakan sebagai nilai kriteria dan masing-masing nilai tersebut dipresentasekan dalam bentuk matriks jika nilai yang dimiliki oleh kriteria tidak dalam bentuk nominal angka maka lakukan terlebih dahulu dilakukan pencarian terhadap nilai yang samar tersebut untuk mendapatkan nilai yang tepat dan sesuai sehingga langkah selanjutnya dapat dilakukan.

2. Normalisasi Matriks

$\bar{x}_{i j}=\frac{x_{i j}}{\sqrt{\sum_{j=1}^{m} X_{I J}^{2}}}$

Pada tahapan ini keseluruhan nilai kriteria yang dimiliki alternatif diberikan pangkat dua dan selanjutnya dijumlahkan, setelah nilai dijumlahkan hitung hasil penjumlahan dengan akar kuadrat untuk menemukan nilai sesungguhnya, misalnya nilai kriteria pertama, keseluruhan nilai kriteria pertama yang dimiliki jumlah alternatif $\mathrm{n}$ dilakukan tahapan proses normalisasi pada keterangan sebelumnya dan setelah hasil diakar kuadratkan masing-masing nilai kriteria dibagi dengan nilai akar kuadrat dan hasil akar kuadrat hanya berlaku untuk tiap nilai krtiteria $i$ dari kriteria $j$.

3. Menentukan matrik normalisasi dengan bobot

$\mathrm{yi}=\sum_{j=1}^{g} w_{j} x_{i j}^{*}-\sum_{j=g+1}^{n} w_{j} x_{i j}^{*}$

pada tahapan ini hasil dari keseluruhan nilai dibentuk kembali menjadi matrik dimana nilainya sudah ternormalisasi, selanjutnya nilai ternormalisasi dikalikan dengan bobot yang sudah ditentukan sebelumnya oleh pihak pemangku kepentingan atau pengambil keputusan, nilai bobot biasanya berbeda tergantung tingkat kepentingan dari kriteria itu tersendiri didalam sebuah permasalahan.

4. Tentukan nilai tertinggi dari keseluruhan hasil

Pada tahapan ini jika nilai kriteria merupakan nilai keuntungan (benefit) dilakukan penjumlahan antara keseluruhan nilai kriteria dan jika terdapat nilai cost makan jumlahkan antara nilai cost saja dan lakukan pengurangan antara benefit dan cost jika terdapat dua unsur tersebut dalam masing-masing kriteria. Pada tahapan ini seluruh nilai yang dimiliki alternatif dijumlahkan dengan keseluruhan kriteria yang dimiliki oleh masing-masing alternatif, nilai tertinggi merupakan alternatif yang harus diberikan perhatian lebih dan menjadi alternatif pilihan dari alternatif lainnya, dan tahapan ini merupakan tahapan akhir dari prosedur penyelesaian masalah menggunakan metode MOORA.

\section{HASIL DAN PEMBAHASAN}

Penyelesaian dengan menggunakan metode MOORA (Multi- Objective Optimization On The Basis Of Ratio Analysis) sangat membantu peneliti dalam menyelesaikan masalah dalam evaluasi kinerja sales untuk 
ISSN 2614-5278 (media cetak), ISSN 2548-8368 (media online)

Available Online at https://ejurnal.stmik-budidarma.ac.id/index.php/mib DOI 10.30865/mib.v5i3.3112

mengefektifkan biaya operasional dikarenakan tahapan yang sederhana dan sangat mudah dipahami dalam perhitungan dalam penggunaan metode MOORA (Multi- Objective Optimization On The Basis Of Ratio Analysis). Hal yang akan diperhatikan dalam evaluasi kinerja sales adalah:

1. sales achievement (pencapaian penjualan)

2. sales call effectivity (efektivitas kunjungan penjualan)

3. sales promotion program

4. kontrol

5. pengolahan resiko

6. market condition (kondisi pasar)

kondisi dan pengalaman sebelumnya memperlihatkan data yang tertera sehingga penilaian akan dilakukan sebagai dampak perubahan positif dalam mengefektifkan biaya operasional, biaya operasional tersebut yang menentukan perusahaan akan tetap bertahan dan berkembang atau berhenti dalam arti gulung tikar.

Tahapan penyelesaian menggunakan metode MOORA (Multi- Objective Optimization On The Basis Of Ratio Analysis) dapat dilihat sebagai berikut ini.

\subsection{Tahapan Penyelesaian MOORA}

Berikut merupakan penyelesaian permasalahan menggunakan metode Moora:

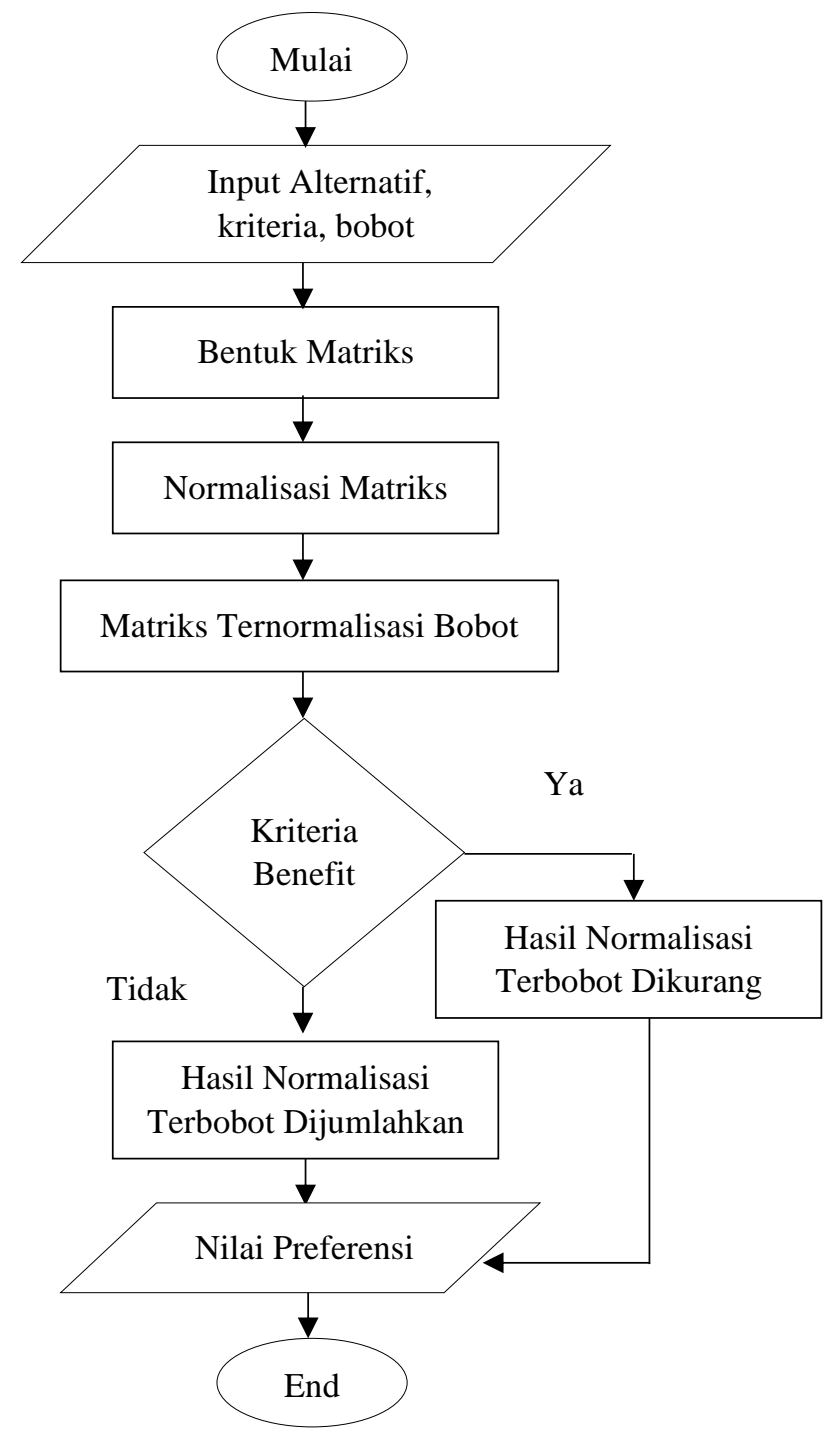

Gambar 1. Tahapan Menggunakan Metode Moora

Pada gambar 1 di atas maka lakukan tahapan penginputan nilai terhadap penentuan alternative, kriteria, dan masing-maisng bobot dan jenis dari kriteria baik benefit maupun cost seperti tabel dibawah ini:

Tabel 1. Nilai Alternatif Terhadap Kriteria 
JURNAL MEDIA INFORMATIKA BUDIDARMA

Volume 5, Nomor 3, Juli 2021, Page 1090-1096

ISSN 2614-5278 (media cetak), ISSN 2548-8368 (media online)

Available Online at https://ejurnal.stmik-budidarma.ac.id/index.php/mib

DOI 10.30865/mib.v5i3.3112

\begin{tabular}{|c|c|c|c|c|c|c|}
\hline & $\begin{array}{c}\text { Sales Achievement } \\
(15 \%)\end{array}$ & $\begin{array}{l}\text { Sales call } \\
\text { Effectivity } \\
(15 \%)\end{array}$ & $\begin{array}{c}\text { Control } \\
\text { Market } \\
(10 \%)\end{array}$ & $\begin{array}{c}\text { Promotion } \\
\text { Program } \\
(25 \%)\end{array}$ & $\begin{array}{c}\text { Market } \\
\text { Condition } \\
(15 \%)\end{array}$ & $\begin{array}{c}\text { Pengolahan } \\
\text { Resiko } \\
(20 \%)\end{array}$ \\
\hline Arisk & Sangat b & Baik & Baik & Cukup Baik & Buruk & Cukup Baik \\
\hline Selia Aggraini (A2) & Baik & Baik & Baik & Cukup & Buruk & Buruk \\
\hline Petran Antono (A3) & Buruk & Cukup Baik & Baik & Baik & Buruk & Cukup Baik \\
\hline Muhammad Rizki (A4) & Sangat baik & Sangat baik & Buruk & Sangat Buruk & Sangat Buruk & Buruk \\
\hline
\end{tabular}

Pada tabel diatas tanpak data dan kualitas pada pekerjaan para sales, keterangan kualitas maupun keterangan terhadap nilai masing-masing alternatif sebagai berikut ini

Tabel 2. Nilai Keteranga Kriteria

\begin{tabular}{ccc}
\hline No & Keterangan & Nilai \\
\hline 1 & Sangat baik & 10 \\
2 & Baik & 8 \\
3 & Cukup Baik & 6 \\
4 & Buruk & 4 \\
5 & Sagat buruk & 2 \\
\hline
\end{tabular}

Sehingga hasil dari masig-maisng nilai krieria yang dimiliki oleh alternatif tersebut adalah sebagai berikut ini:

Tabel 3. Nilai Alternatif Terhadap Kriteria

\begin{tabular}{lcccccc}
\hline & \multicolumn{6}{c}{ Kriteria } \\
\cline { 2 - 7 } & $\begin{array}{c}\text { Sales Achievement } \\
(15 \%)\end{array}$ & $\begin{array}{l}\text { Sales call } \\
\text { Effectivity } \\
(15 \%)\end{array}$ & $\begin{array}{c}\text { Control } \\
\text { Market } \\
(10 \%)\end{array}$ & $\begin{array}{c}\text { Promotion } \\
\text { Program } \\
(25 \%)\end{array}$ & $\begin{array}{c}\text { Market } \\
\text { Condition } \\
(15 \%)\end{array}$ & $\begin{array}{c}\text { Pengolahan } \\
\text { Resiko } \\
(20 \%)\end{array}$ \\
\hline Ariska Chandra & 10 & 8 & 8 & 6 & 4 & 6 \\
Selia Aggraini & 8 & 8 & 8 & 6 & 4 & 4 \\
Petran antono & 4 & 6 & 8 & 8 & 4 & 6 \\
Muhammad rizki & 10 & 10 & 4 & 2 & 2 & 4 \\
\hline
\end{tabular}

Untuk data diatas keseluruhan jenis kriteria merupakan kriteria benefit sehingga penyelesaian masalah dapat dilakukan sebagai berikut ini:

Tabel 4. Penyelesaian dan Hasil

\begin{tabular}{ccccccc}
\hline Tahapan & \multicolumn{7}{c}{ Kriteria } \\
& $\begin{array}{c}\mathrm{C} 1 \\
(15 \%)\end{array}$ & $\begin{array}{c}\mathrm{C} 2 \\
(15 \%)\end{array}$ & $\begin{array}{c}\mathrm{C} 3 \\
(10 \%)\end{array}$ & $\begin{array}{c}\mathrm{C} 4 \\
(25 \%)\end{array}$ & $\begin{array}{c}\mathrm{C} 5 \\
(15 \%)\end{array}$ & $\begin{array}{c}\text { C6 } \\
(20 \%)\end{array}$ \\
\hline Matriks & 10 & 8 & 8 & 6 & 4 & 6 \\
$\sqrt{\sum_{j=1}^{m} X_{I J}^{2}}$ & 16,7332 & 16,248 & 14,4222 & 11,8321 & 7,2111 & 10,198 \\
$\bar{x}_{i j}=\frac{x_{i j}}{\sqrt{\sum_{j=1}^{m} X_{I J}^{2}}}$ & 0,5976 & 0,4923 & 0,5547 & 0,5070 & 0,5547 & 0,5883 \\
$\mathrm{yi}=\sum_{j=1}^{g} w_{j} x_{i j}^{*}-\sum_{j=g+1}^{n} w_{j} x_{i j}^{*}$ & 10 & 10 & 4 & 2 & 2 & 4 \\
\hline
\end{tabular}

Pada akhir tahapan perhitungan data sebagai berikut ini:

Tabel 5. Tabel Akhir

\begin{tabular}{lcccccc}
\hline \multirow{1}{*}{ Alternatif } & Sales Achiev & Sales call & Control & Promotion & Market & Pengolahan \\
& ement & Effectivity & Market & Program & Condition & Resiko \\
\hline Ariska Chandra & 0,089642 & 0,073855 & 0,05547 & 0,126774 & 0,083205 & 0,11767 \\
Selia Aggraini & 0,071714 & 0,073855 & 0,05547 & 0,126774 & 0,083205 & 0,078447 \\
Petran antono & 0,035857 & 0,055391 & 0,05547 & 0,169032 & 0,083205 & 0,11767 \\
Muhammad rizki & 0,089642 & 0,092319 & 0,027735 & 0,042258 & 0,041603 & 0,078447 \\
\hline
\end{tabular}

Selanjutnya data dijumlahkan keseluruhan menghasilkan rangking sebagai berikut ini: 
Tabel 6. Ranking

\begin{tabular}{lcc}
\hline \multicolumn{1}{c}{ Alternatif } & $\mathrm{C} 1+\mathrm{C} 2+\mathrm{C} 3+\mathrm{C} 4+\mathrm{C} 5+\mathrm{C} 6$ & Rank \\
\hline Ariska Chandra (A1) & 0,546616 & 1 \\
Selia Aggraini (A2) & 0,489465 & 3 \\
Petran Antono (A3) & 0,516625 & 2 \\
Muhammad Rizki (A4) & 0,372003 & 4 \\
\hline
\end{tabular}

pada tabel diatas maka dapat dilihat nilai evaluasi Kinerja sales pada sales Ariska Chandra menduduki peringkat pertama sehingga hasil yang diperlihatkan dalam menjalankan pekerjaan sebagai sales sangat baik, diharapkan sales yang lainnya melakukan pekerjaan dengan nilai terbaik demi memaksimalkan dan mengingkatkan efektifitas biaya operasional perusahaan.

\section{KESIMPULAN}

Pada penelitian ini nilai tertinggi merupakan nilai jenis kinerja terhadap sales yang paling banyak mendapatkan keberhasilan dalam kinerjanya dan nilai terendah dapat disimpulkan sebagai alternatif target peningkatan terhadap evaluasi kinerja sales, sehingga setiap kinerja sales yang diberikan maksimal dan mampu mengefektifkan biaya operasional bagi perusahaan, metode MOORA (Multi- Objective Optimization On The Basis Of Ratio Analysis) dengan tahapan sederhana membantu peneliti dalam menyelesaikan penliaian terhadap evaluasi kinerja sales.

\section{REFERENCES}

[1] U. Syarif, "International Journal Administration , Business \& Organization,” vol. 1, no. 1, pp. 10-17, 2020.

[2] V. C. Hardita, E. Utami, and E. T. Luthfi, "Sistem Pendukung Keputusan Pemilihan Sales Terbaik," Creat. Inf. Technol. J., vol. 5, no. 2, p. 138, Jul. 2019.

[3] R. Hiscock, N. H. Augustin, J. R. Branston, and A. B. Gilmore, "Longitudinal evaluation of the impact of standardised packaging and minimum excise tax on tobacco sales and industry revenue in the UK," Tob. Control, p. tobaccocontrol2019-055387, 2020

[4] T. Limbong et al., Sistem Pendukung Keputusan: Metode \& Implementasi. Medan: Yayasan Kita Menulis, 2020.

[5] D. Nofriansyah and S. Defit, Multi Criteria Decision Making (MCDM) pada Sistem Pendukung Keputusan. 2018.

[6] D. Nofriansyah, Multi Criteria Decision Making (MCDM) Pada Sistem Pendukung Keputusan. Yogyakarta: CV.Budi Utama, 2017.

[7] Assrani dkk., "Penentuan Penerima Bantuan Siswa Miskin Menerapkan Metode Multi Objective Optimization on The Basis of Ratio Analysis (MOORA)," JURIKOM (Jurnal Ris. Komputer), vol. 5, no. 2407-389X (Media Cetak), pp. 1$5,2018$.

[8] B. S. Irfan Fandinata and Ginting, "Sistem Pendukung Keputusan Pemilihan Bibit Mangga Terunggul Menerapkan Metode SAW dan WASPAS," vol. 2, no. 1, pp. 27-36, 2018.

[9] S. Manurung, "Sistem Pendukung Keputusan Pemilihan Guru Dan Pegawai Terbaik Menggunakan Metode Moora," Simetris J. Tek. Mesin, Elektro dan Ilmu Komput., vol. 9, no. 1, pp. 701-706, 2018.

[10] Albi Anggito and Johan Setiawan, Metodologi Penelitian Kuantitatif. Jawa Barat: CV Jejak, 2018.

[11] H. Hasanah, "TEKNIK-TEKNIK OBSERVASI (Sebuah Alternatif Metode Pengumpulan Data Kualitatif Ilmu-ilmu Sosial)," At-Taqaddum, vol. 8, no. 1, p. 21, 2017

[12] Moh.Sholik and A. Salam, "Implementasi Algoritma Apriori untuk Mencari Asosiasi Barang yang Dijual di Ecommerce OrderMas,” Techno.COM, vol. 17, no. 2, pp. 158-170, 2018.

[13] A. T. Hidayat, N. K. Daulay, and Mesran, "Penerapan Metode Multi-Objective Optimization on The Basis of Ratio Analysis (MOORA) dalam Pemilihan Wiraniaga Terbaik,” J. Comput. Syst. Informatics, vol. 1, no. 4, pp. 367-372, 2020.

[14] N. K. Daulay, B. Intan, and M. Irvai, "Comparison of the WASPAS and MOORA Methods in Providing Single Tuition Scholarships," IJICS (International J. Informatics Comput. Sci., vol. 5, no. 1, pp. 84-94, 2021

[15] D. Assrani, N. Huda, R. Sidabutar, I. Saputra, and O. K. Sulaiman, "Penentuan Penerima Bantuan Siswa Miskin Menerapkan Metode Multi Objective Optimization on The Basis of Ratio Analysis (MOORA)," Penentuan Penerima Bantu. Siswa Miskin Menerapkan Metod. Multi Object. Optim. Basis Ratio Anal., vol. 5, no. 2407-389X (Media Cetak), pp. 1-5, 2018

[16] K. N. A. Nur, S. R. Andani, and P. Poningsih, "Sistem Pendukung Keputusan Pemilihan Operator Seluler Menggunakan Metode Multi-Objective Optimization on the Basis of Ratio Analysis (Moora)," KOMIK (Konferensi Nas. Teknol. Inf. dan Komputer), vol. 2, no. 1, pp. 61-65, 2018.

[17] C. Fadlan, A. P. Windarto, and I. S. Damanik, "Penerapan Metode MOORA pada Sistem Pemilihan Bibit Cabai (Kasus: Desa Bandar Siantar Kecamatan Gunung Malela),” J. Appl. Informatics Comput., vol. 3, no. 2, pp. 42-46, 2019.

[18] S. Sutarno, M. Mesran, S. Supriyanto, Y. Yuliana, and A. Dewi, "Implementation of Multi-Objective Optimazation on the Base of Ratio Analysis (MOORA) in Improving Support for Decision on Sales Location Determination," in Journal of Physics: Conference Series, 2019.

[19] Mesran, R. K. Hondro, M. Syahrizal, A. P. U. Siahaan, R. Rahim, and Suginam, "Student Admission Assessment using Multi-Objective Optimization on the Basis of Ratio Analysis (MOORA)," J. Online Jar. COT POLIPT, vol. 10, no. 7, pp. 1-6, 2017. 
JURNAL MEDIA INFORMATIKA BUDIDARMA

Volume 5, Nomor 3, Juli 2021, Page 1090-1096

ISSN 2614-5278 (media cetak), ISSN 2548-8368 (media online)

Available Online at https://ejurnal.stmik-budidarma.ac.id/index.php/mib

DOI 10.30865/mib.v5i3.3112

[20] S. Alvita, N. Intan, F. Syahputra, K. Ulfa, and G. L. Ginting, "Sistem Pendukung Keputusan Pemilihan Mekanik Sepeda Motor Terbaik Menggunakan Metode Multi Objective Optimization on The Basis of Ratio Analysis ( MOORA )," vol. 5, no. 1, pp. 66-70, 2018. 